\title{
(Dis)continuation of care of the pre-term newborn at the border
}

\author{
(Des)continuidade do cuidado ao recém-nascido pré-termo em região de fronteira \\ (Des)continuidad del cuidado al recién nacido prematuro en una región de frontera
}

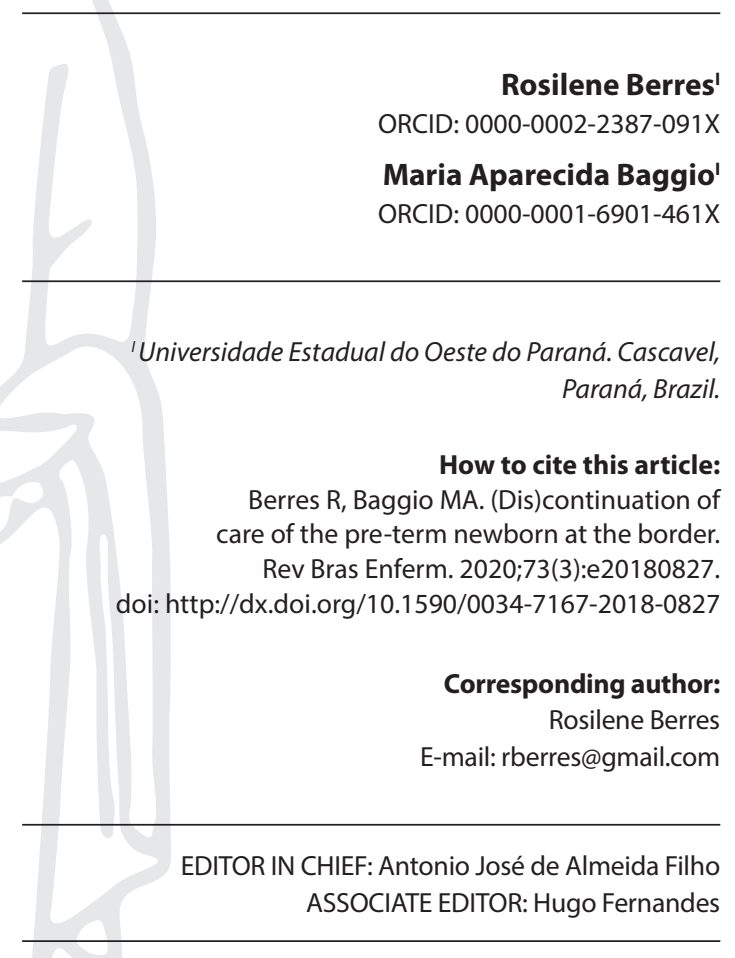

Submission: 10-22-2018

Approval: 03-01-2019

\begin{abstract}
Objectives: to understand how continuation of care for the preterm newborn in the health care network at the border. Methods: the Grounded Theory was the methodological framework. Data were collected through 17 semi-structured interviews between July 2016 and March 2017. Results: "Describing the structure and functioning of the Child Nutrition Center" represents the context; "Experiencing and signifying premature birth" are the causal conditions; "Identifying conditions that intervene in the process of continuation of care for the preterm newborn" are the intervening conditions; "Ensuring continuation of care for the preterm newborn" are strategies; "Identifying (dis)continuation of care flows for the preterm newborn at the border" are the study's consequences and phenomenon. Final Considerations: there is a need to plan referral and counter-referral flows of the preterm newborn and the commitment of public health managers to ensure continuation of care. Descriptors: Child Care; Nursing; Premature Newborn; Border Health; Public Health.
\end{abstract}

\section{RESUMO}

Objetivos: compreender como acontece a continuidade do cuidado ao recém-nascido pré-termo na rede de atenção à saúde na fronteira. Métodos: a Teoria Fundamentada nos Dados foi o referencial metodológico. Os dados foram coletados por meio de 17 entrevistas semiestruturadas, entre julho de 2016 e março de 2017. Resultados:"Descrevendo a estrutura e o funcionamento do Centro de Nutrição Infantil representa o contexto"; "Experienciando e significando o nascimento prematuro" são as condições causais; "Identificando condições que intervêm no processo de continuidade do cuidado ao recém-nascido pré-termo" são as condições intervenientes; "Assegurando a continuidade do cuidado ao recém-nascido pré-termo" são as estratégias; "Identificando fluxos de (des)continuidade do cuidado ao recém-nascido pré-termo em região de fronteira" são as consequências e o fenômeno do estudo. Considerações Finais: identifica-se a necessidade de planejar fluxos de referência e contrarreferência do recém-nascido pré-termo e o comprometimento dos gestores em saúde pública para garantir a continuidade do cuidado.

Descritores: Cuidado da Criança; Enfermagem; Recém-Nascido Prematuro; Saúde na Fronteira; Saúde Pública.

\section{RESUMEN}

Objetivos: comprender cómo ocurre la continuidad del cuidado al recién nacido prematuro en la red de atención de salud en una región de frontera. Métodos: la Teoría Fundamentada en los Datos fue el referencial metodológico. Los datos fueron recolectados por medio de 17 entrevistas semiestructuradas, entre julio 2016 y marzo 2017. Resultados: Describiendo la estructura y el funcionamiento del Centro de Nutrición Infantil representa el contexto; Experimentando y significando el nacimiento prematuro son las condiciones causales; Identificando condiciones que intervienen en el proceso de continuidad del cuidado del recién nacido prematuro son las condiciones intervinientes; Asegurando la continuidad del cuidado al recién nacido prematuro son las estrategias; Identificando flujos de (des)continuidad del cuidado al recién nacido prematuro en una región de frontera son las consecuencias e, igualmente, el fenómeno del estudio. Consideraciones Finales: se identifica la necesidad de planificar flujos de referencia y contrarreferencia del recién nacido prematuro y el compromiso de los gestores en salud pública para garantizar la continuidad del cuidado.

Descriptores: Cuidado del Niño; Enfermería; Recién Nacido Prematuro; Salud Fronteriza; Salud Pública. 


\section{INTRODUCTION}

Annually, 15 million preterm infants are born worldwide, an approximate incidence of one Preterm Newbon (PTNB) for every ten births, whose rates continue to increase. Prematurity is the leading cause of death in children under five. It should be noted that Brazil is among the ten countries with the highest number of premature births ${ }^{(1)}$.

Despite technological and scientific advances, prematurity still presents many challenges, which go beyond the survival and care provided in the hospital environment ${ }^{(2)}$. One of them is the guarantee of continuation of care, after hospital discharge, that ensures comprehensive care for the resolution of a specific health problem, without interrupting the progression of events, that transcends the individual and subjective sphere of the newborn and from his family ${ }^{(3)}$.

PTNB is a fragile being, requiring complex, sensitive and shared health care, and involves families and a network of social and professional support ${ }^{(1)}$. In line with this, continuation of the PTNB care in an European health system is understood as a sequence of integrated health and social support interventions, ensuring quality care and reducing costs; it is considered a timely strategy and a policy to be followed by health services ${ }^{(4)}$.

In Brazil, at the triple border region between Brazil, Paraguay and Argentina, the population's demand for care is beyond expectations, which may hamper the provision of quality care, with integrated health interventions and social support for continuation of care of the newborn at risk, in a timely manner, and free of barriers to effective and accessible care. In addition, the floating population in municipalities at the border makes health services costly to meet a higher number of people than expected ${ }^{(5)}$. Health research at the border is incipient with regard to the care of the PTNB, justifying the relevance of this study.

\section{OBJECTIVES}

To understand how continuation of care for the PTNB happens in the health care network at the border.

\section{METHODS}

\section{Ethical aspects}

The study was approved by the Research Ethics Committee of the Universidade Estadual do Oeste do Paraná. Participants consent was obtained through the signing of the Free and Informed Consent Form. Participants' anonymity was preserved by replacing their names with letters such as PCM for Primary Caregiver Mother, NUR for Nurse, NA for Nursing Assistant, NUT for Nutritionist, PH for Physiotherapist, PS for Psychologist, DOC for Doctor and MAN for Manager. All combinations of letters were followed by the sequential number of the interview, for example: PCM1 - Primary Caregiver Mother 1.

\section{Theoretical-methodological framework}

The Grounded Theory, according to Strauss and Corbin, was used as a method ${ }^{(6)}$.

\section{Type of study}

This is a qualitative study.

\section{Methodological procedures}

The research was developed between July 2016 and March 2017. Inclusion criteria to participate in the research were: a) first sample group: to be the main legal caregiver, responsible for the comprehensive care for the PTNB born in Foz do Iguaçu city, in follow-up at the Child Nutrition Center (CENNI - Centro de Nutrição Infantil) and to live in municipalities of the triple border - Brazil, Paraguay and Argentina. b) second sample group: to be a CENNI health professional working in direct and indirect care for the PTNB. c) third sample group: being a manager at CENNI.

\section{Study setting}

This study was conducted at CENNI of Foz do Iguaçu, Paraná State, Brazil.

\section{Collection and organization of data}

The study consisted of three sample groups, the first group consisting of eight main caregivers (mothers), the second by eight health professionals (two nursing assistants, two nurses, nutritionist, physiotherapist, psychologist and pediatrician) and the third one consisted of a manager, allowing the comparison of the results, the confirmation of hypotheses raised and the formation of the theoretical explanation about the phenomenon investigated ${ }^{(6)}$. The main caregivers were selected and approached personally by the researcher, as they attended the PTNB consultations at CENNI and, by indicating the analyzed data of the first sample group, health service professionals were invited to attend. Interviews were audio-taped and guided by semi-structured script, with an average duration of one hour and thirty minutes.

\section{Data analysis}

Collection and analysis of data were performed concomitantly, according to the open, axial and selective coding steps proposed by the method. In open coding, data were analyzed line by line to define the preliminary categories. The axial coding allowed relating the categories to the subcategories. Finally, selective coding set the central theme of the research. Data were analyzed and discussed according to the paradigmatic model, which explains the phenomenon of the study through five components, namely: context, causal condition, intervening condition, strategy and consequence ${ }^{(6)}$. Data saturation was defined in the repetition of the information and absence of new elements for the consolidation of the categories found.

\section{RESULTS}

The context is described by the category "Describing the structure and functioning of the Child Nutrition Center", a NonGovernmental Organization (NGO), founded in 1993, due to the high number of child deaths due to cases of malnutrition, frequent 
and recurrent at the time. At the time of the study it is specialized outpatient referral for the PTNB in Foz do Iguaçu, Paraná. It has a multiprofessional team composed of pediatrician, nurses, nursing assistants, nutritionist, speech therapist, psychologist, social worker and physiotherapist. It offers outpatient and day care. The latter is intended for children with low weight who require nutritional support, medication administration, particularly antibiotics, when there is risk of the caregiver not administering the dose and correct times. Sustainability depends on the transfer of resources from the Sistemas Integrados de Saúde das Fronteiras (SIS-Fronteiras) program and donations and bazaars.

It's an NGO [...] in 1993, there was a very severe malnourished situation [...] many children who died [...] and founded the Nutrition Center here [...] (MAN1).

[...] Nutrition Center lives through donations ... transfer of the SIS-Fronteiras [...] (NUR3).

Although CENNI is a reference for the PTNB, it also serves other Brazilian children of different age groups living in Brazil or in another country at the border (Paraguay and Argentina).

[...] we do not serve only the preterm ... it's the malnourished, children who have allergies ... celiacs, allergic to lactose. In short, there are several [...] there is no other place[...] (NUR1).

Causal conditions are represented by the "Experiencing and signifying premature birth". For most mothers, primary caregivers, preterm birth was unexpected, even for those followed in a high-risk Brazilian gestation outpatient clinic, with access to information by health professionals. Women in Brazil, Paraguay or Argentina can access this clinic, provided they have Brazilian nationality.

[...] when I did the ultrasound, I said that the baby was fine ... he was going to be born well [...] (PCM1).

In the opinion of study professionals, preterm birth is probably related to the fragility of prenatal care at the border. In addition to the insufficiency of professionals working in the Health Care Network (RAS - Rede de Atenção à Saúde), the coverage of laboratory and imaging exams was restricted or absent in the city of Foz do Iguaçu, at the time of the study, due to health management issues. Professionals add that the unexpected premature birth may also be related to the insufficient information coming from the professionals of the specialized level (high-risk gestation outpatient), related to a gestation of risk, that involves risks for the mother and the baby who were probably not informed.

[...] we have not had any exams for eight months, there is a pregnant woman who is having a child and has not taken any tests [...] (NUR3).

[...] was born with eight months ... because of my high blood pressure. [...] it was na emergency cesarian section [...] (PCM4).

Children's premature birth conditioned the mothers to live the experience of continued care of the newborn at CENNI and brought them closer to the socialization, the exchange of multiple experiences. CENNI health professionals' orientations allowed us to understand the differential neuropsychomotor development time of the preterm child of the term child.

\section{[...] we learn some stuff with other mothers [...] (PCM4).}

[...] the development issue [...] is slower... it is a normal child. [...] We followed the orientations (PCM6).

The category "Identifying conditions that intervene in the process of continuation of care for the preterm newborn" points out the intervening conditions of the study. Mothers and health professionals highlighted some conditions that compromise continuation of care for the PTNB after hospital discharge, which are: lack of definite protocols or flows of the PTNB at RAS after discharge from the hospital (the discharge from the PTNB can occur from the neonatal intensive care unit to the home without the preparation or prior notice of the main caregivers for continuation of care); insufficiency of specialists for follow-up of the PTNB; compromised access to services, particularly laboratory and imaging tests; precarious physical structure of services, especially Primary Care (PC) and CENNI units. Professionals assert that the specialist deficit can be attributed to unsatisfactory remuneration or to their absence. It is pointed out that it is the municipal management that operates the hiring of employees at CENNI, conditions that seem to be related to a problem of municipal health management.

Doctor [...] said ... it's a pound and nine hundred ... you can go home ... the prescription was left in writing with the nurse (PCM3).

\section{$[$ [...] / waited [...] visit my home ... no healthcare professional was (PCM1).}

[...] not having the exams ... laboratory ... ultrasound, tomography [for evaluation of the child's health]. The specialists [...], I am [pediatrician] of the city hall, assigned to CENNI [...],I work at the health center to complete my bond [...] (DOC8).

A amamentação não consolidada e o consequente desmame precoce também são apontadas como condições que comprometem a continuidade do cuidado ao PTNB. The difficulty in taking and sucking, a condition related to prematurity, justified the supply of artificial milk (milk formula) to the newborn, by means of syringe or bottle, still in the hospital environment.

[...] good part of them [preterm] does not have the capacity and strength for suction ... they already arrive [at CENNI] with complement ... of the hospital ... with the pacifier (NUT4).

On the other hand, the reintroduction of breastfeeding or the incentive of exclusive breastfeeding to the PTNB is identified as a condition that favors continuation of care for the PTNB by the CENNI professionals, particularly by the nutritionist and the nurse.

[...] we [CENNI professionals] strongly encourage breastfeeding [...] doing what is possible and impossible not to leave the breast (NUR2).

Also, in this study, another condition that favors continuation of care for the PTNB is the embracement of parents of the PTNB 
living in other countries at the border (Paraguay or Argentina) by relatives living in Brazil. Therefore, having relatives living in Brazil favors the multiprofessional follow-up of the child at CENNI.

There was a boy who was from Paraguay ... he had relatives from Foz do Iguaçu. That was an advantage (NUR5).

The category "Ensuring continuation of care for the preterm newborn" presents the strategies of CENNI health professionals to ensure continuation of care for the PTNB. These professionals understand that caring for a preterm child requires multiple competencies of the main caregivers, especially at home. With emphasis on maternal care for the newborn, they develop health education actions; encourage maternal empowerment; bonding with the family and knowledge of the reality in which the child lives through home visits; and emotional support to caregivers so that they can understand the potential of development of the PTNB, within its particularities.

My job [psychologist] is to show this mother that this child has the potential to develop [...] it will depend on the care of this family [...].I believe we have a team [CENNI professionals] ... committed to the work [...] if it is necessary to do a home visit, we will [...] we see [...] who is supporting this mother [...] to embrace this child and help ... to develop (PS7).

According to the main caregiver' statements, it is important to note the importance of the guidelines provided by health professionals so that they feel safe in the care of the PTNB, demystifying the fears.

She [nurse] taught me ... breastfeed [...] And then the bath... and the medicine $[. .$.$] (PCM3).$

The category "Identifying (dis)continuation of care flows for the preterm newborn at the border" triggers the phenomenon, which points to a disordered care flow for the child who was born prematurely in the different contexts of health care at the mentioned border. The referral and counter-referral system does not present defined, organized and structured flows for access to the CENNI, regardless of the country of origin of the families, whose child was born prematurely in Brazilian territory, since it is a border region.

At hospital discharge, primary caregivers are not adequately oriented on which service will continue the child care, probably due to the lack of defined flows. Children's access to the CENNI can happen by reference to PC or counter-referral from the hospital or the Emergency Care Unit (ECU), or by spontaneous search of the primary caregiver. On weekends, public holidays and outside CENNI office hours, the main caregivers seek the ECU in case of need for child care, by spontaneous demand or forwarded by the hospital (the hospital serves children less than 28 days old). The ECU, in turn, responds to emergencies and emergencies. Finally, it is evident that the PC does not participate in continuation of care for the child concomitant with CENNI; except for immunization, which compromises the formation of the child and his family's bond with the PC and the articulation of the RAS and the professionals in the care for the PTNB.
In fact, these children, up to age two, basically do not go to the basic [health network], just come here [CENNI]. There they apply the vacciness... (NUR2).

According to the paradigmatic model of the study, represented by the previously described categories and their components, the phenomenon of "(dis)continuation of care for the PTNB at the border", whose model of child care at RAS presents a disarticulation between the different levels of health care. In addition, CENNI is not a formal service from RAS, but an NGO that seeks to suppress a repressed demand of the municipality.

\section{DISCUSSION}

Preterm birth may lead to a higher risk of morbidity and mortality compared to full-term children, considering the physiological immaturity and the possible intercurrences and iatrogenies resulting from hospitalization. As a consequence of survival, physical, cognitive and social delays may occur, including neuropathologies, auditory and visual impairments, motor development retardation, eating disorders, learning disabilities, among others ${ }^{(7)}$.

In Brazil, there are health policies that although important for the advances and improvements in the field of Public Health, are not sufficiently implemented to serve the population, specifically to $\mathrm{PTNB}^{(8)}$. In this way, the State contracts outpatient services of medium and high complexity to meet the needs of service provision $^{(9)}$.

NGOs are members of the Voluntary Sector (Third Sector), a merger between the public and private, and work to meet public and social needs, assuming a legal administrative characteristic of direct private, non-profit ${ }^{(10)}$ In Foz do Iguaçu, in order to attend cases of child malnutrition, in the 90 's, CENNI was created; an NGO with which the municipality maintains partnership through an agreement for outpatient child care, whose sustainability occurs through the transfer of funds to the NGO. However, this NGO seems to need to develop specialized care actions for the PTNB with competence of the $P C^{(8)}$, showing an important fragility of these services in the RAS at this border.

With the prospect of expanding the right to health for the population residing at the border, which includes the children of this study, the Sistema Integrado de Saúde das Fronteiras (SISFronteiras) was established between 2009 and 2011. However, despite efforts to decentralize the Brazilian health system, in an attempt to improve service to the border population, obstacles still impede the implementation of an effective service network, including child care services. The main difficulties relate to the programming of actions due to distinctions in the health policies of the countries involved and the procedures for financing, which have not yet been transposed ${ }^{(11)}$.

Prenatal care is essential to prevent preterm birth and should be started in the first trimester of pregnancy to monitor maternal and fetal health. Quality prenatal care involves undertaking laboratory and imaging tests to identify and treat early complications inherent to pregnancy, which appear to be restricted or absent to the caregivers participating in the study. Therefore, the unexpected premature birth refers to an inadequate prenatal care, either in quantity or quality of the consultations ${ }^{(12)}$. 
Unexpected premature birth, possibly as a consequence of health mismatch, triggered ambiguous and contradictory feelings towards caregiver mothers. Believing in the recovery and full development of the child denotes a close relationship with the bond and trust put on the CENNI health professionals ${ }^{(13)}$.

The fragility of the child born premature causes impacts and creates fear for its clinical instability. Child hospitalization experience alters the daily life and dynamics of the family ${ }^{(14)}$. However, the confidence put in CENNI health professionals in continuation of newborn care after discharge; the interaction with other mothers who lived a pre-term childcare experience with the service and the help of close people favors overcoming uncertainties arising from the uncertain and insecure universe of prematurity. This situation, as demonstrated in another study, is accompanied by suffering, stress and concern, whose mothers/ families would like to forget ${ }^{(14)}$. It is verified the importance of health professionals to widen the gaze for care extended to the entire PTNB family, either in the experience during the period of hospitalization or in continuation of care after discharge ${ }^{(8)}$.

There is no reason why the PTNB should be discharged without the caregiver receiving all the fundamental guidelines about adequate and safe care at home, as identified in the study. Health team guidance should be clear and accurate in order to promote health and impart knowledge to the whole family ${ }^{(15)}$.

Thus, planning for home discharge should be exercised strategically and individually, considering the specificities of each family and the health condition of each baby. Caregivers could feel more confident and confident if there was adequate preparation and orientation for the discharge of the PTNB. However, in addition to the fact that they were not prepared and oriented about home care, they were not, in most situations, oriented towards monitoring the health of children after discharge ${ }^{(16)}$. Thus, it is confirmed that the task of ensuring counter-referral is entrusted to caregivers, which renders vulnerable continuation of care for the PTNB ${ }^{(17)}$.

In the organizational arrangement of RAS, interconnection, interaction and integration between the different actions and services are necessary for continuation of care for the PTNB at the border. Inadequate articulation among network health professionals, particularly among the specialized and hospital PC services (in this study conformed by the NGO professionals) points out the need for professionals to be in constant communication. It is from the PC and not from the NGO, as it is seen here, the competence to carry out the active search by means of a home visit for the follow-up of the absent PTNB to health care so that outpatient follow- establish the promotion of the health of the PTNB ${ }^{(18)}$. For this, it is necessary the effective communication between the professionals of the network, interconnecting specialized and hospital PC.

The study confirms that feeding a PTNB involves multiple factors and may culminate in the non-consolidation of breastfeeding. A PTNB has difficulty suckling the mother's breast commonly due to a lack of coordination between sucking, swallowing, and breathing. Suction can lead to weight loss by energy expenditure. However, as soon as the child shows signs of clinical progression, breastfeeding should be encouraged ${ }^{(19)}$.

A PTNB's mother is faced with multiple barriers that tend to limit breastfeeding and this requires that health professionals be aware of the difficulties that may arise to make it effective ${ }^{(14)}$. Health and nursing professionals can support and encourage mothers to overcome challenges and difficulties, from hospitalization in an intensive neonatal environment, in order to consolidate breastfeeding, a condition not identified in the study.

The setting studied is a border, in which families migrate from one country to another to improve their living conditions in terms of access to health. Argentinian or Paraguayan mothers of the PTNB born in Brazil, who had relatives residing in Brazilian territory, continued the care for the PTNB at the favored CENNI, probably due to the dry border between the countries, with proximity to the urban areas, typical of that border region ${ }^{(20)}$.

Continuation of care for the Brazilian PTNB is favored by the Brazilian legislation. It provides universal and free access to health services at all levels of care and, overseas, access to emergency and emergency services, unlike Paraguay and Argentina, whose countries have a social security system based on employment, which interferes with access to citizens' health ${ }^{(20-21)}$. In addition, it should be noted that the better structure, supply, resolution and quality of Brazilian health services, in relation to the Paraguayan and Argentinean systems, influence migratory flows, as well as the heterogeneity in the levels of development of each country ${ }^{(21)}$. This justifies the PTNB families flow to Brazil.

Embracing and organized health services in networks can maximize continuation of care for the preterm child by recognizing their problems, their particularities and singularities, as well as their family. To do so, these services should support families whenever they need them, regardless of the number of times they seek them ${ }^{(22-23)}$. These attitudes characterize accountability for care of the other. Once responsible for care, strategies can be proposed to strengthen the continuation of health care for the PTNB, particularly when families migrate between border regions to ensure access to health.

The great challenge to ensure continuation of care for the PTNR after hospital discharge is based on adequate support for these children and their families. Therefore, it is the responsibility of health professionals, a priori the nurse, to propose strategies that help in adapting PTNB to the home environment, by an extended approach, aimed at meeting the family needs for the PTNB care. Health education, the use of information and guidelines appropriate to the understanding of each caregiver ensure understanding and develop competence for care ${ }^{(2)}$.

It is confirmed by the study that mothers who feel empowered to care for the child understand the importance of continuing home care after discharge. This consequently reduces demand for specialized services as well as decreases the demand for emergency and urgency services and possible readmissions ${ }^{(24)}$. This justifies the encouragement of professionals to maternal empowerment to ensure continuation of care for the child.

Again, it is through the home visit that the professionals can know the dynamics of the families and the context in which they live. It also allows the addressing of issues of interest, with guidelines that guide parents' choices and decision-making for their care, focusing on the promotion of positive parenting and the maximum potential for development of the PTNB ${ }^{(25)}$. Moreover, visits favor the establishment of the professional's relationship with the family ${ }^{(26)}$, a strategy confirmed by the study data to ensure continuation of care for the PTNB. 
Access of the preterm child to the NGO (developer of PC actions and specialized care clinic) generates insecurity for families, but also for health professionals, occurring in a disorganized, disjointed, dissociated way, varying between referrals made by the hospital, by the ECU, or by spontaneous demand of families. However, this does not prevent the latter from providing care for this population, although the lack of communication between hospital and PC professionals in the referral and counter-referral process is an impediment to the follow-up of care practices ${ }^{(17-18)}$.

The study confirms the fragility of health services, particularly of the $\mathrm{PC}$, due to its non-participation in continuation of child care concomitant with the CENNI, except for immunization. It corroborates that emergency and early care are alternatives for families in order to solve the low and medium complexity health problems of their children ${ }^{(23,27)}$. Therefore, the difficulty in access, follow-up and resolving of child care in the PC that focused on the disease, centered on the doctor's figure, shows the need for programmatic care for the preterm, not only attention acute problems caused by complications arising from prematurity and in the consultation ${ }^{(23,27-28)}$.

Articulation between the hospital and the PC should be configured in a care line, started in prenatal care, still in the Basic Health Unit (BHU), with identification of the gestational risk; followed by the hospitalization of the mother and the newborn and continued with the follow-up of the newborn, the mother and the family in the different contexts of care, such as the BHU, the specialized service or the home through home visits ${ }^{(8)}$. Therefore, it is asserted that although the preterm child needs specialized care, PC follow-up should happen. This is because the BHU is closer to the families and to be able, through the reception and bond, to take better care of the problems presented by prematurity. Therefore, it is understood that the PC service should be the computer of the care for the PTNB ${ }^{(22)}$.

When the population does not enjoy the various levels of complexity due to the lack of a cohesive flow, having to face bureaucratic and disjointed services, it means that health services are not effective. It is necessary that the supply be reviewed and the strategies of health care rethought through a process of (re) organization of services to resolve this impasse ${ }^{(29)}$. Health promotion and the development of the PTNB will depend, in addition to the engagement of the family, on the interaction established between each of these services ${ }^{(8)}$.

As a response to this problem, the health services require a structuring based on the essential attributes of PC, such as access, longitudinality, comprehensiveness and coordination, in order to consider the comprehensive health needs of the child, the family and the environment in who live ${ }^{(27)}$.
Regional, geographic and social inequalities in Brazil, particularly in this study, developed at a border, is a fragility that is configured in an important public health problem that affects the supply and financing of services, as well as the distribution of health professionals. It should be noted that the concept of border includes spaces shared by the border population, in the mutual dependence between countries, whose epidemiological and health dynamics becomes complex, since they comprise an identity that transcends territorial boundaries ${ }^{(30)}$.

Finally, in order to improve the Brazilian health system, it is necessary to have equitable access, effectiveness and efficiency of services to the population, with resources allocated to improve health coverage, especially in regions and populations of greater vulnerability, such as of this study ${ }^{(31)}$.

\section{Study limitations}

The study was limited to collecting data in a single network service. It is suggested research in other services to a greater understanding of the phenomenon in different contexts.

\section{Contributions to the fields of Nursing, Health or Public Policy}

The study presents a contribution to public policies, identifying the need to plan referral and counter-referral streams of the PTNB, with articulation between different levels of health care and adequate orientation to families, considering that the spaces are shared by the border population.

\section{FINAL CONSIDERATIONS}

Understanding the phenomenon of (dis)continuation of care for the PTNB at the border identifies the need to plan referral and counter-referral streams of the PTNB, with articulation between different levels of health care and adequate guidance to families. It is suggested that PC be the guideline of continuation of care for the PTNB and its family, concomitant to the other services of the network, considering that they are shared by the population living at the border.

Strategies for coping with conditions that interfere with and condition the discontinuation of the PTNB care are necessary. Above all, there is a need for commitment of public health managers, since the main demands can be met if there is an adequate supply of services and professionals to care for the PTNB, with a proper structure of services to families and decent working conditions for professionals, which can guarantee continuation of care.

\section{REFERENCES}

1. World Health Organization. Preterm birth [Internet]. 2018 [cited 2018 Aug 07]. Available from: http://www.who.int/news-room/fact-sheets/ detail/preterm-birth

2. Castro ACO, Duarte ED, Diniz IA. Intervenção do enfermeiro às crianças atendidas no ambulatório de seguimento do recém-nascido de risco. Rev Enferm Cent-O Min [Internet]. 2017 [cited 2017 Aug 11];7:e1159. Available from:http://www.seer.ufsj.edu.br/index.php/recom/article/ view/1159/1321

3. Freitas LFC, Moreira DA, Brito MJM. The continuity of care from the perspective of the being cared for. Cogitare Enferm [Internet]. 2014 [cited 2018 Mar 20];19(4). Available from: http://revistas.ufpr.br/cogitare/article/view/35993/23929 
4. Mendes FRP, Gemito MLGP, Caldeira EC, Serra IC, Casas-Novas MV. Continuity of care from the perspective of users. Ciênc Saúde Coletiva [Internet]. 2017 [cited 2018 Mar 20];22(3). Available from: http://www.scielo.br/pdf/csc/v22n3/1413-8123-csc-22-03-0841.pdf

5. Albuquerque JLC. Limites e paradoxos da cidadania no território fronteiriço: o atendimento dos brasiguaios no sistema público de saúde de Foz do Iguaçu (Brasil). Geopolítica(s) [Internet]. 2012 [cited 2017 Sep 26];3(2). Available from: https://revistas.ucm.es/index.php/GEOP/ article/viewFile/40040/40396

6. Santos JLG, Erdmann, AL, Sousa FGM, Lanzoni GMM, Melo ALSF, Leite JL. Methodological perspectives in the use of grounded theory in nursing and health research. Esc Anna Nery [Internet] 2016 [cited Mar 20];20(3):e20160056. Available from: http://www.scielo.br/pdf/ean/ v20n3/1414-8145-ean-20-03-20160056.pdf

7. Koç Ö, Kavuncuoglu S, Ramoglu M, Aldemir E, Aktalay A, Eras Z. School performance and neurodevelopment of very low birth weight preterm infants: first report from turkey. J Child Neurol [Internet]. 2015 [cited 2018 Apr 17];31(2):170-6. Available from: http://journals. sagepub.com/doi/full/10.1177/0883073815587028

8. Ministério da Saúde (BR). Secretaria de Atenção à Saúde. Departamento de Ações Programáticas Estratégicas. Atenção humanizada ao recém-nascido: Método Canguru: manual técnico [Internet]. 3. ed. Brasília (DF); 2017 [cited 2016 Aug 21];340p. Available from: http://bvsms. saude.gov.br/bvs/publicacoes/atencao_humanizada_metodo_canguru_manual_3ed.pdf

9. Romano CMC, Scatena JHG, Kehrig RT. Articulação público-privada na atenção ambulatorial de média e alta complexidade do SUS: atuação da Secretaria de Estado de Mato Grosso. Physis. [Internet] 2015 [cited 2017 Aug 21];25(4):1095-115. Available from: http://www.scielo.br/ pdf/physis/v25n4/0103-7331-physis-25-04-01095.pdf

10. Bergenthal, F. Gestão da Informação Orgânica para a Tomada de Decisão em uma ONG: estudo de caso na Brahma Kumaris [TCC] [Internet]. Porto Alegre (RS): Universidade Federal do Rio Grande do Sul; 2015 [cited 2017 Aug 21]. Available from: http://www.lume.ufrgs.br/ handle/10183/135008

11. Nogueira VMR, Fagundes HS. A implementação do SIS Fronteiras - perspectivas para a ampliação do direito à saúde na Fronteira Arco Sul. Serv Soc Saúde[Internet]. 2014 [cited 2018 Apr 17];13(2)(18):245-60. Available from: https://periodicos.sbu.unicamp.br/ojs/index.php/sss/ article/view/8634903/2801

12. Tomasi E, Fernandes PAA, Fischer T, Siqueira FCV, Silveira DS, Thumé E, et al. Qualidade da atenção pré-natal na rede básica de saúde do Brasil: indicadores e desigualdades sociais. Cad Saúde Pública [Internet]. 2017 [cited 2017 Aug 21];33(3):e00195815. Available from: http:// www.scielo.br/pdf/csp/v33n3/1678-4464-csp-33-03-e00195815.pdf

13. Silva RMM, Menezes CCS, Cardoso LL, França AFO. Vivências de famílias de neonatos prematuros hospitalizados em unidade de terapia intensiva neonatal: revisão integrativa. Rev Enferm Cent-O Min [Internet]. 2016 [cited 2017 Sep 26];6(2):2258-70. Available from: http:// www.seer.ufsj.edu.br/index.php/recom/article/view/940/1108

14. Pereira, LB, Abrão ACFV, Ohara CVS, Ribeiro CAM. Maternal experiences with specificities of prematurity that hinder breastfeeding. Texto Contexto Enferm[Internet]. 2015 [cited 2017 Aug 10];24(1):55-63. Available from: http://www.scielo.br/pdf/tce/v24n1/0104-0707-tce-24-01-00055.pdf

15. Frota MA, Silva PFR, Moraes SR, Martins EMCS, Chaves EMC, Silva CAB. Alta hospitalar e cuidado do recém-nascido prematuro no domicílio: vivência materna. Esc Anna Nery [Internet]. 2013 [cited 2017 Sep 26];17(2):277-83. Available from: http://www.scielo.br/pdf/ean/v17n2/v17n2a11.pdf

16. Silva RMM, Viera CS. Acesso ao cuidado à saúde da criança em serviços de atenção primária. Rev Bras Enferm [Internet]. 2014 [cited 2017 Sep 26];67(5):794-802. Available from: http://www.scielo.br/pdf/reben/v67n5/0034-7167-reben-67-05-0794.pdf

17. Aires LCP, Santos EKA, Bruggemann OM, Backes MTS, Costa R. Reference and counter-reference health care system of infant discharged from neonatal unit: perceptions of primary care health professionals. Esc Anna Nery [Internet]. 2017 [cited 2018 Aug 24];21(2):e20170028. Available from: http://www.scielo.br/pdf/ean/v21n2/en_1414-8145-ean-21-02-e20170028.pdf

18. Aires LCP, Santos EKA, Costa R, Borck M, Custódio ZAO. Seguimento do bebê na atenção básica: interface com a terceira etapa do método canguru. Rev Gaúcha Enferm[Internet]. 2015 [cited 2018 Aug 24];36(Spe):224-32. Available from: http://www.scielo.br/pdf/rgenf/ v36nspe/0102-6933-rgenf-36-spe-0224.pdf

19. Damasceno JR, Silva RCC, Ximenes Neto FRG, Ferreira AGN, Silva ASR, Machado MMT. Nutrição em recém-nascidos prematuros e de baixo peso: uma revisão integrativa. Rev Soc Bras Enferm Ped [Internet]. 2014 [cited 2018 Aug 24];14(1):40-6. Available from: https://sobep.org.br/ revista/images/stories/pdf-revista/vol14-n1/v14_n1_artigo_revisao_2.pdf

20. Sousa, LLS; Neri, FS; Villavicencio, JLS; Silva, MG. Pactos, protocolos e o protagonismo dos atores políticos locais: impasses e condicionantes para o acesso aos bens e serviços de saúde na linha de fronteira do arco sul do Mercosul. Rev Bras Inic Científ [Internet]. 2018 [cited 2018 Nov 15];5(2):200-10. Available from: https://periodicos.itp.ifsp.edu.br/index.php/IC/article/view/1214

21. Aikes, S; Rizzotto, MLF. Regional integration of healthcare services in twin cities, Paraná State, Brazil. Cad Saúde Pública [Internet]. 2018 [cited 2018 Nov 15];34(8):e00182117. Available from: http://www.scielo.br/pdf/csp/v34n8/1678-4464-csp-34-08-e00182117.pdf

22. Silva RMM, Toso BRGO, Neves ET, Nassar PO, Zilly A, Viera CS. Resolutividade na atenção à criança com necessidades especiais de saúde. Rev Pesqui Qualit [Internet]. 2017 [cited 2018 Aug 20];5(7):23-37. Available from: https://editora.sepq.org.br/index.php/rpq/article/view/50/61

23. Neves ET, Buboltz FL, Silveira A Kegler JJ, Silva JH, Santos RP, Zamberlan KC. Rede de apoio de familiares de crianças em pronto atendimento pediátrico. Rev Pesqui Qualit [Internet]. 2017 [cited 2018 Aug 20];5(7):53-65. Available from: https://editora.sepq.org.br/index.php/rpq/article/view/74/63

24. Santos ND, Thiengo MA, Moraes JRMM, Pacheco STA, Silva LF. O empoderamento de mães de recém-nascidos prematuros no contexto de cuidado hospitalar. Rev Enferm UERJ[Internet]. 2014 [cited 2018 Aug 24];22(1):65-70. Available from: http://www.facenf.uerj.br/v22n1/ v22n1a10.pdf 
25. Mello DF, Silva RMM, Pancieri L. Êxito técnico e sucesso em visita domiciliar para o cuidado da saúde da criança. Rev Pesqui Qualit [Internet]. 2017 [cited 2018 Aug 20];5(7):13-22. Available from: https://editora.sepq.org.br/index.php/rpq/article/view/46/60

26. Braga PP, Sena RR. Avanços na atenção ao prematuro e a continuidade da assistência: reflexão sobre rede de cuidados. Rev Enferm Cent. Min [Internet]. 2013 [cited 2017 Aug 21];3(3):899-908. Available from: http://www.seer.ufsj.edu.br/index.php/recom/article/view/442/537

27. Buboltz FL, Silveira A, Neves ET. Estratégias de famílias de crianças atendidas em pronto-socorro pediátrico: a busca pela construção da integralidade. Texto Contexto Enferm[Internet]. 2015 [cited 2017 Sep 26];24(4):1027-34. Available from: http://www.scielo.br/pdf/tce/v24n4/ pt_0104-0707-tce-201500002040014.pdf

28. Finkler AL, Viera CS, Tacla MTGM, Toso BRGO. O acesso e a dificuldade na resolutividade do cuidado da criança na atenção primária à saúde. Acta Paul Enferm [Internet]. 2014 [cited 2018 Aug 24];27(6):548-53. Available from: http://www.scielo.br/pdf/ape/v27n6/1982-0194ape-027-006-0548.pdf

29. Arruda C, Lopes SGR, Koerich MHAL, Winck DR, Meirelles BHS, Mello ALSF. Health care networks under the light of the complexity theory. Esc Anna Nery [Internet]. 2015 [cited 2018 Aug 24];19(1):169-73. Available from: http://www.scielo.br/pdf/ean/v19n1/en_1414-8145ean-19-01-0169.pdf

30. Mello F, Victora CG, Gonçalves F. Saúde nas fronteiras: análise quantitativa e qualitativa da clientela do centro materno infantil de Foz do Iguaçu, Brasil. Ciênc Saúde Coletiva [Internet]. 2015 [cited 2018 Aug 24];20(7):2135-45. Available from: http://www.scielo.br/pdf/csc/ v20n7/1413-8123-csc-20-07-2135.pdf

31. Oliveira APC, Gabriel M, Dal Poz MR, Dussault G. Challenges for ensuring availability and accessibility to health care services under Brazil's Unified Health System (SUS). Ciênc Saúde Coletiva [Internet]. 2017 [cited 2018 Aug 24];22(4):1165-80. Available from: http://www.scielo.br/ pdf/csc/v22n4/en_1413-8123-csc-22-04-1165.pdf 